\title{
Alternative Binders for Increased Sustainable Construction in Ghana-A Guide for Building Professionals
}

\author{
Mark Bediako, Augustine Osei Frimpong \\ Council for Scientific and Industrial Research—Building and Road Research Institute, Materials Division, Kumasi, Ghana. \\ Email: b23mark@yahoo.com
}

Received October 25 $5^{\text {th }}$, 2013; revised November $29^{\text {th }}$, 2013; accepted December $8^{\text {th }}$, 2013

Copyright (C 2013 Mark Bediako, Augustine Osei Frimpong. This is an open access article distributed under the Creative Commons Attribution License, which permits unrestricted use, distribution, and reproduction in any medium, provided the original work is properly cited.

\begin{abstract}
Sustainable concepts and practices have taken a centre-stage in different fields of studies and professions. This is because human activities continue to threaten the carrying capacity of earth resources as well as life basic needs such as shelter. Ghana, a developing nation, has been characterized with a boom in construction activities. In almost every constructional work, Portland cement remains the main binding agent that is used to bind aggregates together in a monolithic unit. The overdependence of the Ghanaian construction industry on Portland cement has contributed to huge sums of foreign exchange used to import cement ingredients, high cost of buildings and annual artificial shortages of cement which leads to high cost of the product. In this work, alternative binding agent-pozzolana cement, is reported with regards to the theory behind its utilization, laboratory results and practical applications. Results obtained from both the laboratory and the field works have shown that the future binder for the Ghanaian construction industry is pozzolana cement. CSIR-Building and Road Research Institute recommends it for the construction industry for use in various forms of construction such as block making, concrete and mortar works.
\end{abstract}

Keywords: Sustainable; Carrying Capacity; Alternative Binder; Foreign Exchange; Pozzolana Cement

\section{Introduction}

Globally the idea of sustainability has now taken a centre stage in different field of studies. The automobile Industry is now moving towards biodiesels and fuels, likewise the construction industry which is shifting towards green buildings, cementless construction technology, blended cements all encapsulated as sustainability concepts. Sustainability in the global context has been defined in so many forms and ways by different authors. However, the most referred definition is the one defined by the committee once lead by the former prime minister of Norway in 1987, Prime Minister Brundtland. This committee which was formed by the United Nations kick started global sustainability awareness since the world as a globe was being threatened by human factors leading to scarcity of resources, global warming and cyclones (tsunamis, tornados, etc.). According to the Brundtland committee, sustainability is defined as developments that meet the needs of the present without compromising the ability of the future generation to meet their own needs [1].

The definition by the Brudtland committee suggests three important components of sustainable development and these are: 1) what is to be sustained, 2) what is to be developed, and 3) the intergenerational components. Components that need to be sustained include nature, life support systems and communities. Those components that need to be developed involve people, society and economy whilst the intergenerational components are the finite nature of the earth resources which can provide intergenerational equity [2,3]. In 2000, the United Nations gave birth to the millennium development goals but has now been turned into sustainability development goals headed by the former Prime Minister of Britain, Gordon Brown. This suggests how important sustainability pursuance is so necessary in this 21st century.

The problem of the cement industry is mainly centered on economical, environmental and technical issues. In the economic dimension, almost all cement inputs used 
by the cement manufacturing companies; clinker and gypsum are imported with huge amount of foreign exchange which is over $\$ 250$ Million. This is coupled with high inflation and interest rate which tends to affect the price built up of a $50 \mathrm{~kg}$ bag of cement in the country. The consequences of the annual cement price increase over the years have contributed to undue projects delay, construction of indecent makeshift dwelling places for most low-income earners, which has resulted into slums especially in our urban cities.

The environmental concern focuses on overexploitation of natural resources such as limestone, clay, etc and release of harmful gaseous substance into the global environment from the cement industries worldwide. The effect of these gases on the atmosphere has resulted in a rise of earth atmospheric temperature which has led to global warming creating catastrophic situations such as flooding, droughts and cyclones for human existence on earth. The cement industry globally contributes between $5 \%$ and $8 \%$ of the total carbon dioxide emission $[4,5]$. The global carbon emission of carbon dioxide, a major anthropogenic gas in 2012, was approximately 36 billion tonnes [6]. The fight against global warming is a difficult one which needs collaborative effort from different countries both the developed and the underdeveloped nations.

The technical problem focuses on the harsh nature and the exothermic behaviour of cement after hydration. Moreover, cement products such as concrete and mortar after hydration may have some components leaching out from cement matrix resulting in the creation of tiny pores in concrete and mortar. These problems of cement lead to extreme shrinkage cracks, aggressive chemical attacks such as chloride, sulphates. In our system here in Ghana one common problem of cement based products is concrete dampness which normally occurs at the bottom part of many buildings.

Being aware of all the enormous problems that the cement industry poses on the planet and our country, Chemical and Material engineers in CSIR-BRRI have over many years researched extensively on alternative materials that can be used to lower cement quantity in a cubic or square meter of mortar, concrete and block works. In this work, alternative binding agent-pozzolana cement, is reported with regards to the theory behind its utilization, laboratory results and practical applications. The main aim of the study is to elucidate the importance of clay pozzolana in the Ghanaian construction industry.

\section{Literature Review}

\subsection{What Is Pozzolana?}

Pozzolana is defined as a siliceous or alumino-siliceous material, which in itself possesses little cementitious value, but will in finely divided form and in the presence of water chemically reacts with free lime from cement at ordinary temperature to form compounds possessing cementitious properties $[7,8]$. Pozzolana occurs naturally and artificially. Examples of natural pozzolanas are volcanic glasses and ashes, tuff, trass and Santorin earth all found in the US and part of Europe. Artificial pozzolanas include flyash, shales, diatomaceous earth, industrial byproducts (silica fume, granulated slag), rice husk ash and calcined clays. Fly ash produced from coal combustion is the most widely used pozzolanic material in the world. Singh and Garg [9] reported that the use of calcined kaolonitic clay as a pozzolanic material is not very popular and again supported by Coleman and Page [10].

Pozzolana produced from clay has received considerable interest from some researchers such as Samet et al. [11], Wild et al. [12], Atiemo [13], and Sabir et al. [14]. Clay pozzolana in the last decade has essentially been linked with construction of sea water and dams in countries like Brazil, Denmark, France, England, USA, India and Egypt [12]. Clay pozzolana is processed from high kaolin clay by calcinations at moderate temperatures $\left(650^{\circ} \mathrm{C}-800^{\circ} \mathrm{C}\right)$.

In 2000, clay pozzolana was commercialised as a material which could be utilized to replace up to about $40 \%$ of cement. Figure 1 illustrates the production flow chart of clay pozzolana production. After two years of commercial production in CSIR-BRRI, the institute partnered with a new company called Pozzolana Ghana Limited (PGL), set-up another commercial plant in the central part of Ghana. Since then, the two pozzolana producing factories in the country produce approximately 10,000 tonnes of pozzolana annually. The utilization of clay pozzolana in the Ghanaian construction industry is fairly a new practice and according to a recent survey most building professionals lack the basic knowledge regarding its use. Though the technology is new in the country yet it is an old construction practice known to ancient builders including early Greek and Roman masons.

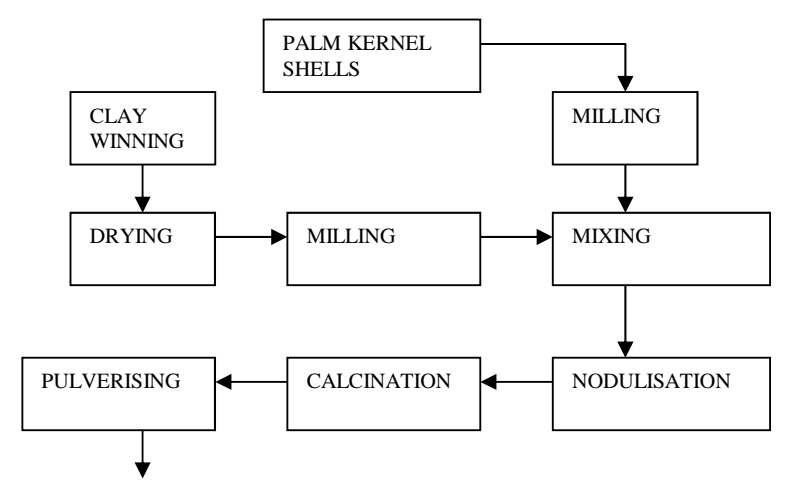

Figure 1. Production flow chart for clay pozzolana. 


\subsubsection{Theory of Pozzolanic Action with Portland Cement during Hydration}

When Portland cement (PC) and water are mixed together, hydration occurs. The hydration process generates basically two products, calcium silicate hydrate $(\mathrm{CSH})$ and lime $\left(\mathrm{Ca}(\mathrm{OH})_{2}\right)$. Figure 2 presents the microstructure of cement grains depicting the $\mathrm{CSH}$ and $\mathrm{Ca}(\mathrm{OH})_{2}$. About $28 \%$ of free lime $\left[\mathrm{Ca}(\mathrm{OH})_{2}\right]$ is liberated from a fully hydrated or matured concrete or mortar [15]. Free lime from PC hydration does not make any signifi- cant contribution and could be harmful to concrete and mortar durability. Free lime is also found to have a higher affinity for sulphates and chlorides which is mostly dangerous to concrete and sulphates. It also has the characteristics of leaching out from a cement matrix. Figure 2 presents a microstructural view of a hydrated cement paste

The addition of pozzolana to PC is characterized by a chemical reaction between metakaolinite and free lime given by the chemical equation below [14]

$$
\underset{\substack{\mathrm{Al}_{2} \mathrm{O}_{3} \cdot 2 \mathrm{SiO}_{2} \\ \text { Metakaolin }}}{\text { Lime }}+\underset{\text { Water }}{5 \mathrm{Ca}(\mathrm{OH})_{2}}+\underset{\text { Tetracalcium aluminate hydrate }}{19 \mathrm{H}_{2} \mathrm{O}} \rightarrow \underset{\mathrm{Al}_{2} \mathrm{O}_{3} \cdot 4 \mathrm{CaO} \cdot 19 \mathrm{H}_{2} \mathrm{O}}{\text { Watcium silicate hydrate }}
$$

The reaction forms a secondary CSH gel together with crystalline products which include calcium alumino hydrates and alumino silicate hydrate. The hydration products formed due to pozzolanic action refines the pores of the products making mortars and concretes denser and less porous to chemical attacks (sulphates and chlorides). Free lime crystals structure formed is minimize due to grain refinement as a result of pozzolanic action.

\subsubsection{Characteristics of Pozzolanic Reaction}

Pozzolanic reaction has some characteristics and these include the following:

1) Slows down cement hydration hence lower early strength development;

2) Attains high strength at a late stage;

3) Controls heat of hydration in minimizing it;

4) Minimize pore structures.

The cement hydration slow-down is attributed to the nature of pozzolanic reaction. At the early days of cement hydration containing pozzolana, the pozzolanic materials become inactive and serve as a cover over the cement grains inhibiting their reaction with water. At

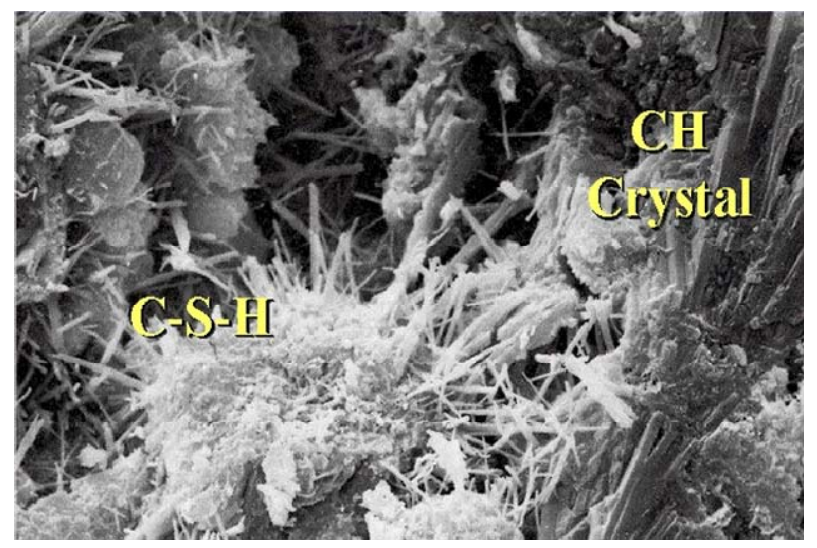

Figure 2. Microstructure of cement grain showing CSH and $\mathrm{Ca}(\mathrm{OH})_{2}$. Source: Bediako et al. [16]. later days, the inactive pozzolanic powder dissociates into solution to form reactive silicates. At this same late age, available $\mathrm{Ca}(\mathrm{OH})_{2}$ present in solution reacts with the dissolved silicates from the pozzolanic materials to form secondary CSH which increase the later age strength. The minimization of hydration heat of cement containing pozzolana is attributed to the dilution effect of cement compounds by pozzolanic materials. The cement compounds include tricalcium aluminate $\left(\mathrm{C}_{3} \mathrm{~A}\right)$, tricalcium silicate $\left(\mathrm{C}_{3} \mathrm{~S}\right)$ and dicalcium silicate $\left(\mathrm{C}_{2} \mathrm{~S}\right)$. Pore structure minimization also results from particle size of the two materials, pozzolana and cement. Mostly, pozzolanic materials are very fine than cement hence refines the cement structure pores.

\subsubsection{The Importance of Pozzolanic Materials in Construction}

The importance of pozzolanic materials in construction could be viewed from these three different angles; economics, ecological and technical.

In the economic sense, the production of pozzolanic materials is far less expensive than Portland cement. In the cement industry, energy is one of major cost component. The pozzolanic producing companies use almost half of the energy which is used to produce Portland cement. This has a net effect of cost reduction with respect to pozzolana utilization. The production of less expensive pozzolanic material could lead to affordable concrete and mortar formation, provision of less expensive buildings. Moreover approximately \$100 Million could be saved from cement importation through the use of locally produced pozzolana in Ghana.

From the ecological perspective, pozzolanic materials contribute little effect to the environment as compared to cement production in terms of $\mathrm{CO}_{2}$ emissions. The Kyoto protocol which came into being in 1997 highlights the principle of Clean Development Mechanism (CDM). $\mathrm{CDM}$ allows emission reduction in developing countries. 
In contributing to the global net effect of $\mathrm{CO}_{2}$ emission, then the need to use more of pozzolanic materials and less of cement will help to achieve this aim.

From the technical view point, since pozzolanic materials refine pore structure of cement by making it denser, it will mean that there will be reduction of chemical attacks, early shrinkage and minimize the leaching action of cement compounds.

\section{Experimental Program and Results of Some Clay Pozzolana and Cement Mixes}

\subsection{Experimental Program}

Some clay samples from three different areas, Mankranso, Mfensi and Tanoso have been developed for pozzolana production. Mankranso and Mfensi are located in Ashanti region whereas Tanaoso is located in the Brong Ahafo region all in Ghana. These selected sites were chosen because of the abundance of clay in these areas. Water demand or normal consistency, setting times and compressive strength were investigated on paste and mortars respectively. Portland cement was replaced with pozzolana at $10 \%, 20 \%, 30 \%$ and $40 \%$ to formulate both binder pastes and mortars.

Water demand and setting time test (both initial and final) were determined on the binder paste. This test was determined in accordance to the EN 197-1 standards. This standard prescribes the use of the Vicat apparatus. According to EN 197-1, the water demand also known as normal consistency is determined with a plunger. The water demand is reached when the plunger penetrates the paste and reading on the scale records $6 \pm 2$. The initial set time occurs when a Vicat needle penetrates the binder specimen to a point $5 \pm 1 \mathrm{~mm}$ from the bottom of the mould. The final setting also occurs at the time the needle with a ring fails to make impression on the surface of the specimen.

Compressive strength test was determined on blended mortars in accordance with ASTM C109 standard. The mortar specimens were prepared at 1:3 binder to sand ratio and a water to cement ratio of 0.50 at normal temperature $\left(24^{\circ} \mathrm{C}\right)$. The prepared mortar mixes were filled in a $70.6 \mathrm{~mm}$ metallic cube moulds and arranged on an electric vibrator which was turned on for 2 minutes to ensure good compaction of the mortar. After casting, the mortar specimens were covered with a wet cloth in order to control water evaporation from the mortar during the hydration process for $24 \mathrm{hrs}$. The compressive strength was determined on an average of 3 mortar specimens after curing in potable water for 2, 7 and 28 days.

\subsection{Results and Discussions}

Table 1 presents the water demand, setting times and the compressive strength of Portland pozzolana cement (PPC) pastes and mortars at $10 \%-40 \%$ of pozzolana. PPC strength values were determined on an average of three mortar cubes. It is shown from Table 1 that as pozzolana content increases the water demand and the setting time also increases. The increase in water demand could be attributed to the porous nature and the high surface area of pozzolana powder material than Portland cement. The increase in the setting times could be due to the decrease in the stiffening agent, cement within the matrix. From the table, the compressive strength values were found increasing with curing days. This shows the formation of new hydration products with time which enhances strength formation.

Early age strength at 2 days and 7 days of PPC mortars between $10 \%$ and $30 \%$ pozzolana replacement were similar to the control. PPC mortars of Mankranso, Mfensi and Tanoso pozzolanas at $10 \%$ and $20 \%$ replacement were $9 \%-13 \%, 8 \%-11 \%$ and $5 \%-11 \%$ higher than the control at 28 days respectively. Figure 3 show that $30 \%$ of pozzolana mortars at 28 days gave strength values comparable to the EN 197-1 standard which is $32.5 \mathrm{MPa}$. From Figure 3, the increase in the amount of replacement to $40 \%$ reduced the strength at 28 days for all the three PPC mortars.

\section{Important Laboratory Results Worth Considering}

The laboratory results show some important findings. These are:

1) At $30 \%$ replacement of cement by pozzolana produces Portland Pozzolana Cement (PPC);

2) The percentage replacement meets the EN 197-1 standards of $32.5 \mathrm{~N}$ for Portland cement;

3) Mass, reinforced and prestressed concrete could be produced suitably with 20\%, 25\% and 30\% cement replacement by clay pozzolana.

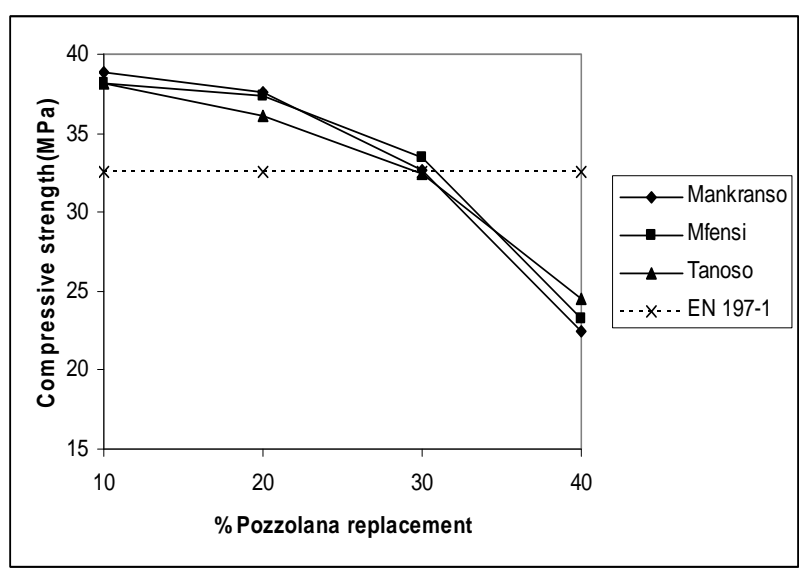

Figure 3. 28 days strength of Mankranso, Mfensi and Tanoso. Source: Atiemo et al. [13]. 
Table 1. Water demand, setting times and compressive strength of pozzolana cement mixes.

\begin{tabular}{|c|c|c|c|c|c|c|c|}
\hline \multirow{2}{*}{ Mix } & \multirow{2}{*}{ \% Pozzo content } & \multirow{2}{*}{$\%$ Water demand } & \multicolumn{2}{|c|}{ Setting times (mins) } & \multicolumn{3}{|c|}{ Compressive strength (MPa) } \\
\hline & & & Initial & Final & $2 d$ & 7d & 28d \\
\hline Control & 0 & 26.8 & 90 & 196 & 14.9 & 20.5 & 34.5 \\
\hline \multirow[t]{4}{*}{ Mankranso } & 10 & 30 & 125 & 210 & 19.8 & 22.67 & 38.9 \\
\hline & 20 & 33 & 173 & 225 & 17.4 & 21.1 & 37.6 \\
\hline & 30 & 35 & 184 & 246 & 16.2 & 17.5 & 32.7 \\
\hline & 40 & 38 & 200 & 287 & 11.8 & 13 & 22.5 \\
\hline \multirow[t]{4}{*}{ Mfensi } & 10 & 28.7 & 88 & 190 & 20.4 & 23.7 & 38.2 \\
\hline & 20 & 31 & 105 & 215 & 18.2 & 20.9 & 37.4 \\
\hline & 30 & 39.2 & 195 & 252 & 17.3 & 18.6 & 33.5 \\
\hline & 40 & 42.5 & 210 & 295 & 11.4 & 12.6 & 23.3 \\
\hline \multirow[t]{4}{*}{ Tanoso } & 10 & 28 & 95 & 210 & 19.5 & 21.61 & 38.2 \\
\hline & 20 & 32 & 173 & 225 & 20.1 & 21.6 & 36.1 \\
\hline & 30 & 37 & 184 & 246 & 15.8 & 18.9 & 32.4 \\
\hline & 40 & 39.2 & 171 & 260 & 11.2 & 12.1 & 24.5 \\
\hline
\end{tabular}

Source: Atiemo et al. [13]; Bediako et al. [5].

\section{Experience Use of Clay Pozzolana}

From the time of clay pozzolana commercialization till date, the product has been used together with cement for many successful projects. The institute has produced simplified brochures and leaflets that aid builders on the application of pozzolana. Appendix 1 shows a sample a leaflet indicating snappy details of pozzolana application for commercial users of the product. Clay pozzolana has been utilised for various construction project in almost all the ten regions of Ghana. Some of the projects undertaken between 2010 and 2012 are listed below. Appendix 2 contains pictures of these selected projects that used pozzolana

- Mortar for brick bonding at Aboadze thermal plant, Takoradi;

- Block making by a commercial concrete products producer, Kumasi;

- Ongoing BRRI main Administration building, Foundation works, Kumasi;

- Market centre in Kumasi;

- Office complex for Electricity Company of Ghana Building in Kumasi.

\section{Conclusions}

The following conclusions are made from this study:

1) The use of pozzolana is not new in the construction industry however new in Ghana.

2) Experimental data supporting the utilization of clay pozzolana meet Ghana and international standards i.e.
GS 964 and ASTM C618 specifications.

3) Green construction, ecocement, etc. are now the new terminologies taking a center stage for the now and the construction of the future. Pursuance of these would ensure a significant preservation of significant natural resources.

4) Pozzolana utilization in the Ghanaian construction industry could afford cost efficiency and would also reduce the importation of cement into the country.

5) In thinking about the environment, less energy intensive materials like pozzolana could be used for our benefit. This could promote sustainable construction practice.

\section{REFERENCES}

[1] H. M. Hosseini and S. Kaneko, "Dynamic Sustainability Assessment of Countries at the Macro Level: A Principal Component Analysis,” Ecological Indicators, Vol. 11, No. 3, 2011, pp. 811-823. http://dx.doi.org/10.1016/j.ecolind.2010.10.007

[2] N. Arman, J. Zuo, L. Wilson, G. Zilante and S Puller, "Challenges of Responding to Sustainability with Implications for Affordable Housing," Ecological Economics, Vol. 68, No. 12, 2009, pp. 3034-3041. http://dx.doi.org/10.1016/j.ecolecon.2009.07.007

[3] M. W. Anderson, M. Tiesl and C. Noblet, "Giving Voice to the Future in Sustainability: Retrospective Assessment to Learn Prospective Stakeholder Engagement,” Ecological Economics, Vol. 84, 2012, pp. 1-6. http://dx.doi.org/10.1016/j.ecolecon.2012.09.002

[4] J. M. Alwood, J. M. Cullen and R. L. Milford, “Option 
for Achieving a 50\% Cut in Industrial Emissions by 2050," Environmental Science and Technology, Vol. 44 No. 6, 2010, pp. 1888-1894.

http://dx.doi.org/10.1021/es902909k

[5] J. Faludi, "Concrete: A Burning Issue, World Changing," 2004. www.worldchanging.com

[6] J. G. J. Olivier, G. Janssen-Maenhout and J. A. H. W. Peters, "Report on Trends in Global $\mathrm{CO}_{2}$ Emissions," European Commission Joint Research, Netherlands, 2012.

[7] V. M. Malhotra and R. T. Hemmings, "Blended Cement in North America-A Review," Cement and Concrete Composites, Vol. 17, No. 1, 1995, pp. 23-35. http://dx.doi.org/10.1016/0958-9465(95)95757-Q

[8] M. A. Coldarone, K. A Gruber and R. G Burg, "High Reactivity Metakaolin: A New Generation Mineral Admixture," Concrete International, Vol. 16, No. 11, 1994, pp. 37-40.

[9] M. Singh and M. Garg, "Reactive Pozzolana from India Clays-Their Use in Cement Mortars," Cement and Concrete Research, Vol. 36, No. 10, 2006, pp. 1903-1907. http://dx.doi.org/10.1016/j.cemconres.2004.12.002

[10] N. J. Coleman and C. L. Page, "Aspects of the Pore Solution Chemistry Hydrated Cement Pastes Containing MK," Cement and Concrete Research, Vol. 27, No. 1, 1997, pp.
147-154.

http://dx.doi.org/10.1016/S0008-8846(96)00184-6

[11] B. Samet, T. Mnif and M. Chaaboni, "Use of Kaolinitic Clay as a Pozzolanic Material for Cements: Formulation of Blended Cement," Cement and Concrete Composite, Vol. 29, No. 10, 2007, pp. 741-749. http://dx.doi.org/10.1016/j.cemconcomp.2007.04.012

[12] S. Wild, J. M. Khatib and A. Jones, "Relative Strength Pozzolanic Activity and Cement Hydration in Superplasticised MK Concrete," Cement and Concrete Composite, Vol. 26, No. 10, 1997, pp. 1537-1544.

[13] E. Atiemo, "Production of Pozzolana from Some Local Clays-Prospects for Application in Housing Construction," Journal of the Building and Road Research Institute, Vol. 9, No. 1-2, 2005, pp. 34-37.

[14] B. B. Sabir, S. Wild and J. Bai, "Metakaolin and Calcined Clays as Pozzolanas for Concrete: A Review," Cement and Concrete Composites, Vol. 23, No. 6, 2001, pp. 441454. http://dx.doi.org/10.1016/S0958-9465(00)00092-5

[15] R. N. Swamy, "Fly Ash Concrete-Potential without Misuse,” Materials and Structures, Vol. 23, No. 6, 1990, pp. 397-411.

[16] M. Bediako, "Utilization of Some Ghanaian Mineral Admixtures for Masonry Mortar Formulation,” Unpublished MPhil Thesis, KNUST, Ghana, 2010. 


\section{Appendix 1}

BRIEF DESCRIPTION OF POZZOLANA Pozzolana Ghana Ltd (PGL) is a wholly-owned subsidiary of PMC Global incorporated of the USA which operates in 16 countries worldwide. For over 30 years of extensive research into pozzolana cement, the CSIR-BRRI in partnership with PGL has commercialised pozzolana cement for construction industries in Ghana, having its main plant at Gomoa in the Central Region and the research plant at Fumesua near Kumasi.

ADVANTAGES OF USING CLAY

POZZOLANA FOR CONSTRUCTION

- Produces cost-efficient mortar and concrete

- Improves the workability of mortar and concrete

- Reduces the heat of hydration, bleeding and segregation of concrete

- Minimizes the effect of sulphate attack in concrete and mortar.

- Reduces effect of alkali aggregate reactivity

- More suitable for polluted environment like - abandoned refuse dump sites, elc.

- Pozzolana is an environmentally safe and a natural resource of Ghana

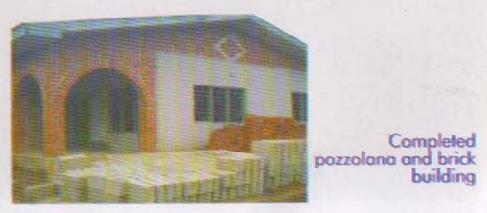

USES OF CLAY POZZZOLANA

A lot of successful projects have been undertaken using Portland Pozzolana Cement. They include:

- Sandcrete blocks

-

- Floor beds

- Culverts

- Pavementblocks

- Kerbs

- Drains

- Rendering and plastering

- Biogas lanks

DIRECTIONS FOR USE OF POZZOLANA

Step One

- Mix Pozzolana with Portland cement in

recommended ratio in dry state.

- Add the blended cement to the sand or stones (where necessary).

- Mix all the materials very well to form a uniform mix.

Step Two

- Gradually, add water to the materials from step

one. Ample use of water is recommended. Step Three

- Use it for your work to get a fine finishing.
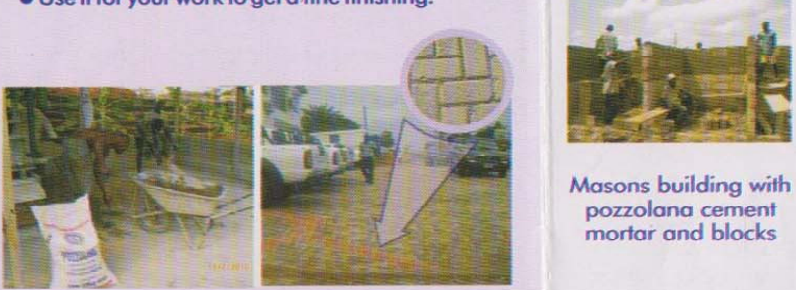

Masons building with pozzolana cement mortar and blocks using $3: 1$ Portiand cement/ pozzolano ratio

Pozzolana leaflet used as quick reference by building professionals.

\section{Appendix 2: Pictures of some projects that used clay pozzolana.}

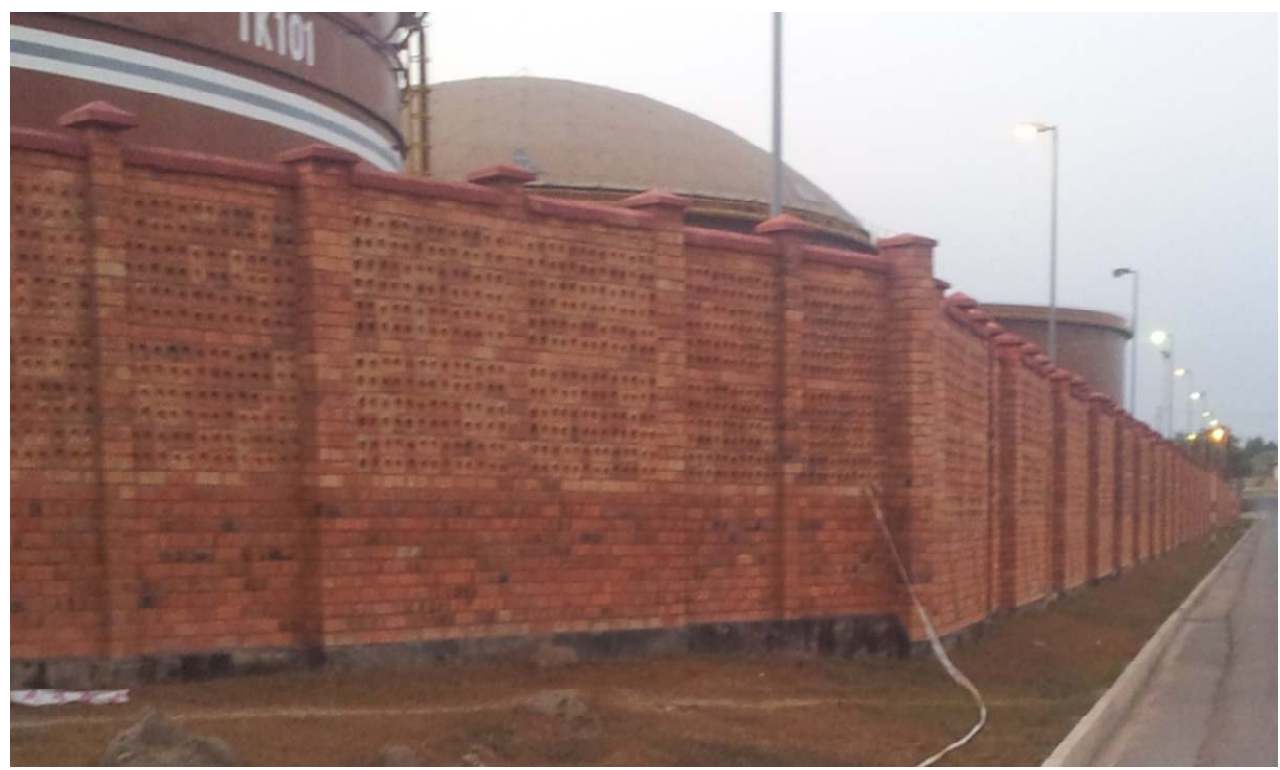

Mortar used for brick bonding, CSIR-BRRI walling project at Aboadze, Takoradi. 


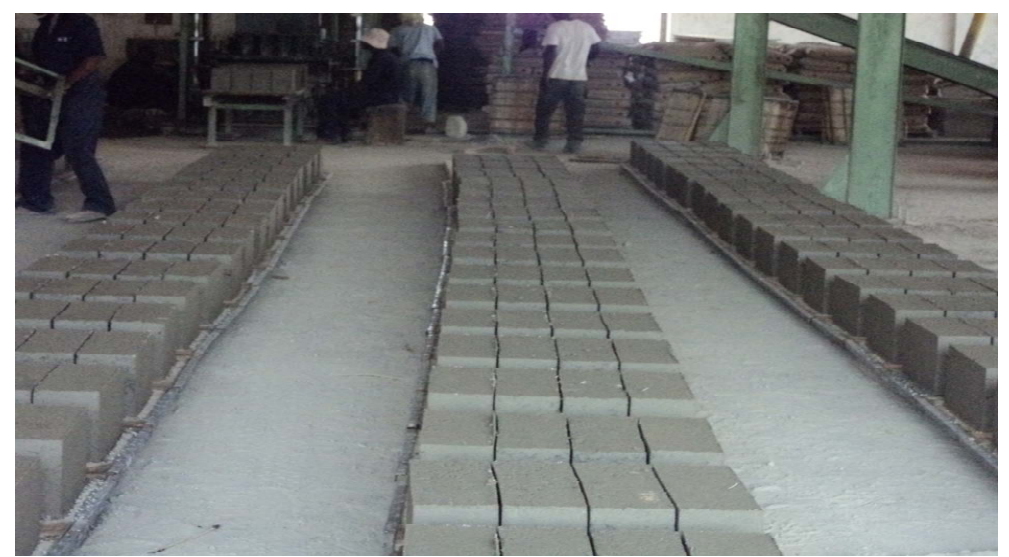

Block making by Naa Achiaa concrete products, Kumasi.

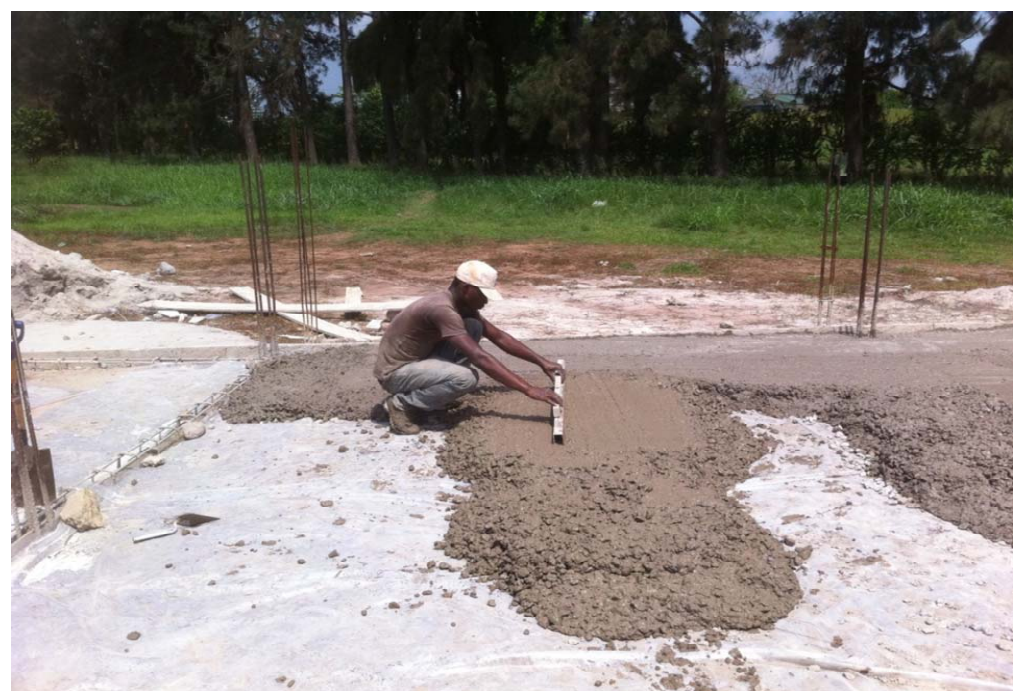

Mass concrete for foundation works.

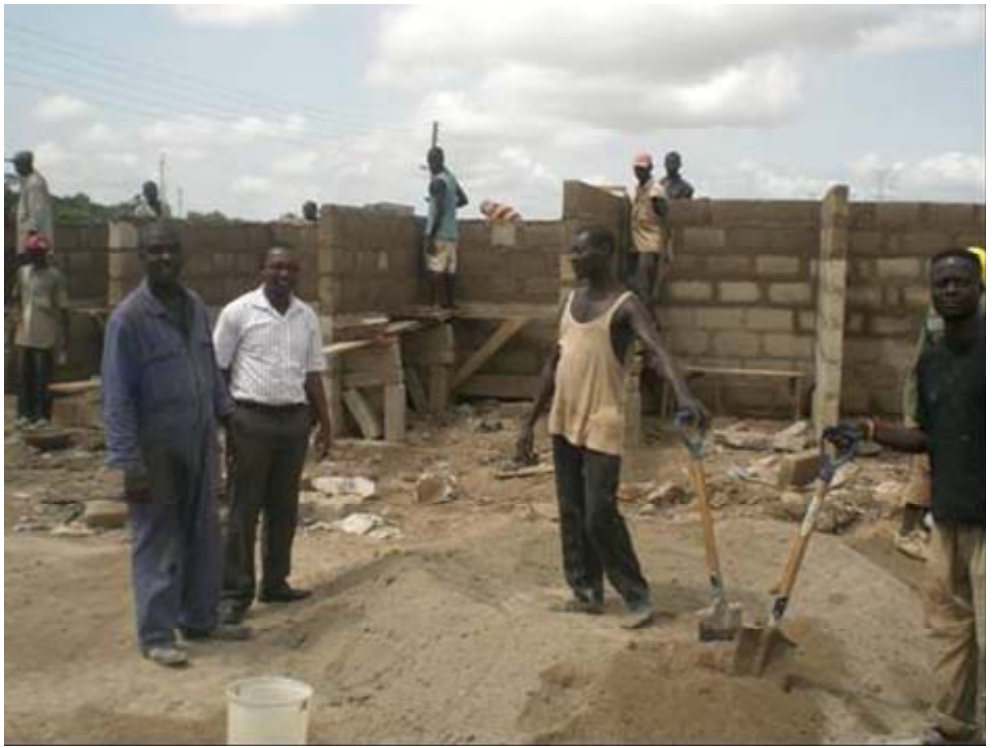

Preparation of cement-pozzolana mortar for the construction of market stalls in Kumasi. 


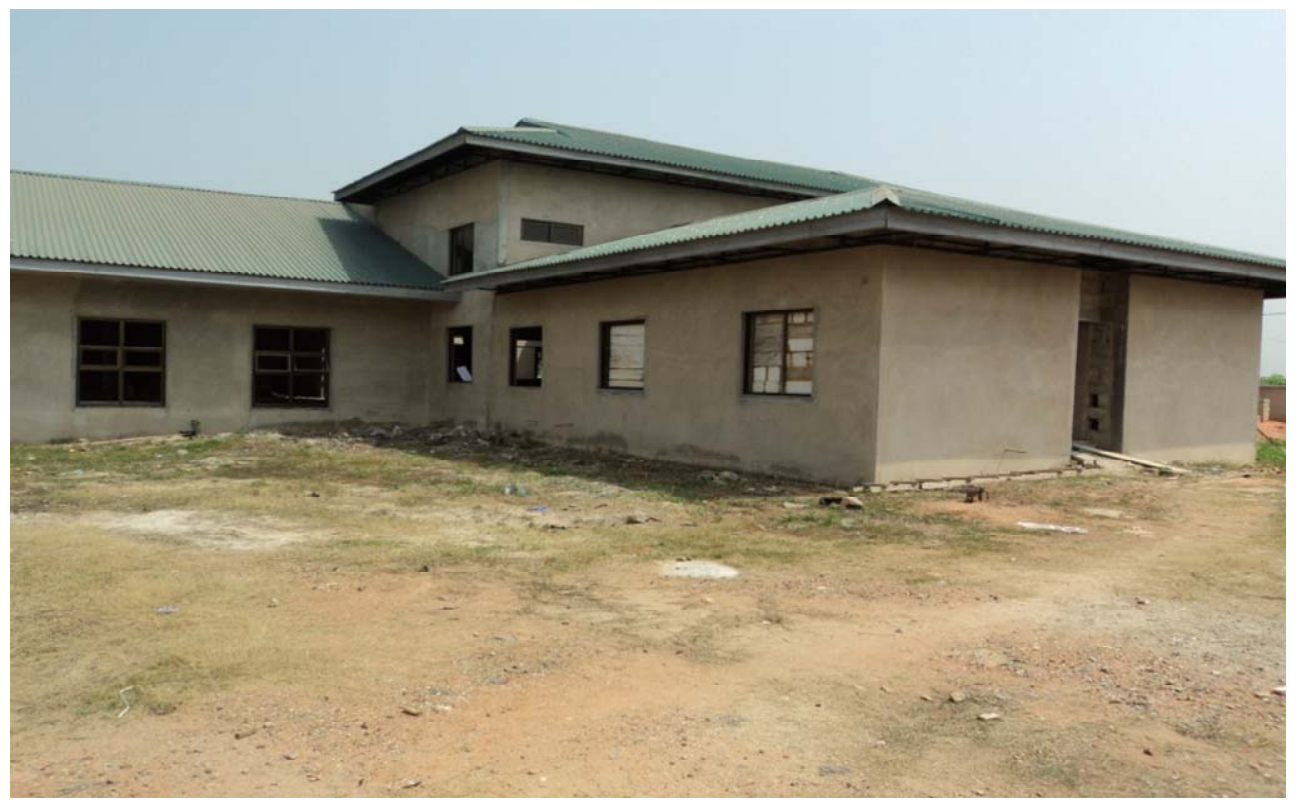

Office complex under construction for Electricity Company of Ghana in Kuamsi. 